\title{
Optimization of a Fragment-Based Screening Hit towards Potent DOT1L Inhibitors Interacting in an Induced Binding Pocket
}

Clemens Scheufler, Henrik Möbitz, Christoph Gaul, Christian Ragot, Céline Be, Cesar Fernandez, Kim S. Beyer, Ralph Tiedt and Frédéric Stauffer*

Novartis Institutes for Biomedical Research, Basel, Switzerland

Supporting Information

Table of content

Figure $\mathrm{S} 1$ and $\mathrm{S} 2 \quad 2$

Experimental procedures for the synthesis of 2-10 2

$\begin{array}{ll}\text { Dot1L SPA assay } & 16\end{array}$

$\begin{array}{ll}\text { Dot1L SPR assay } & 16\end{array}$

Experimental procedure for the generation of the Dot1L cocrystal structures 16

$\begin{array}{ll}\text { References } & 17\end{array}$ 


\section{Figures S1 and S2}

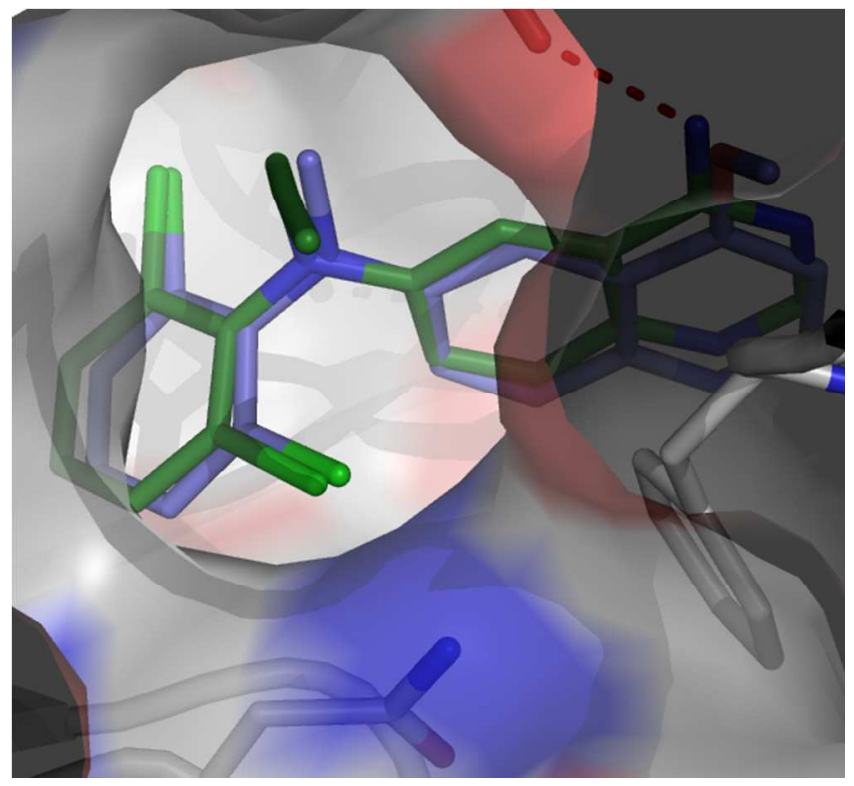

Figure S1. Docking of compound 6 (green) in the co-crystal structure of DOTiL.5 (grey/blue) demonstrates the potential of the propargyl linker to extend through the narrow hydrophobic channel

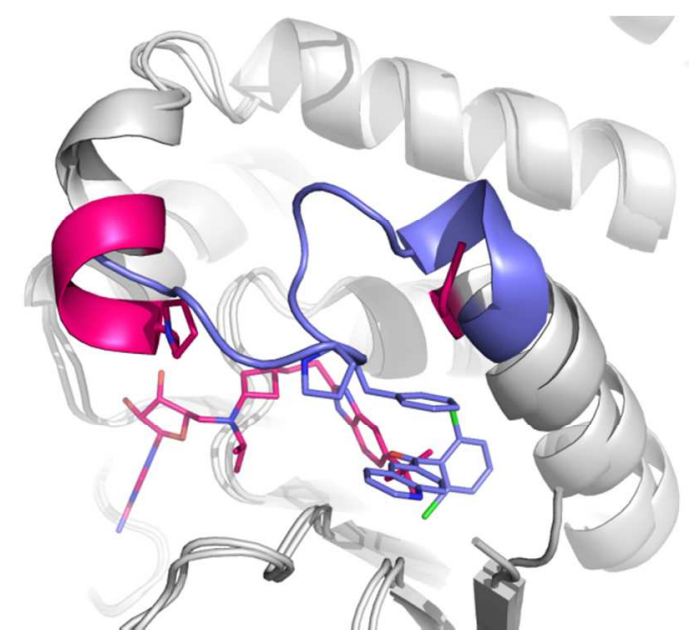

Figure S2. Superimposition of EPZ-5676 bound DOT1L co-crystal structure (PDB 4HRA) and compound 3 bound DOT1L cocrystal structure (PDB 5DTQ). The ligand and lid loop of the SAM binding pocket (residues 126-140, Pro130 and Phe131 shown as sticks) are coloured in blue for Dot1L.3 and magenta for Dot1L.EPZ-5676. The flexible loop 296-309 at the crystal interface is omitted for clarity.

\section{Experimental procedures for the synthesis of 2-10}

General Methods. All reagents and solvents were of commercial quality and used without further purification. Normal phase column chromatography purifications were carried out in the indicated solvent system (volume:volume) using pre-packed Silica RediSepRf $®$ cartridges for use on the ISCO CombiFlash $\AA$. Nuclear Magnetic Resonance spectra were recorded on Bruker $400 \mathrm{MHz}$ or $600 \mathrm{MHz} /$ $54 \mathrm{~mm}$, UltraShield ${ }^{\mathrm{TM}}$ Plus, long hold time spectrometers. Spectra were taken in the indicated solvent at 
ambient temperature and the chemical shifts are reported in parts per million (ppm $(\delta)$ ) relative to the lock of the solvent used. Resonance patterns are recorded with the following notations: s (singlet), $d$ (doublet), $\mathrm{t}$ (triplet), $\mathrm{q}$ (quartet) and $\mathrm{m}$ (multiplet). The LC-MS analyses ( $\mathrm{t} t=$ retention time) were performed with a Waters Acquity UPLC BSM, coupled to a Waters Acquity SQD (Single Quadrupole Detector) mass spectrometer with a range of ESI +/- : 100-1200 m/z, utilizing a Waters Acquity HSS T3 $1.8 \mu \mathrm{m} 2.1 \times 50$ $\mathrm{mm}$ column with $60^{\circ} \mathrm{C}$ column temperature, a flow of $1 \mathrm{~mL} / \mathrm{min}$ and a solvent gradient 5 to $98 \%$ B over 1.4 min, followed by $0.4 \mathrm{~min}$ at $98 \% \mathrm{~B}$; solvent $\mathrm{A}$ : water $+0.05 \%$ formic acid $+3.75 \mathrm{mM}$ ammonium acetate, solvent $B$ : acetonitrile $+0.04 \%$ formic acid. The injection volume was $1 \mu \mathrm{l}$ and the solvent was typically $\mathrm{MeOH}$. MS analyses $(\mathrm{m} / \mathrm{z})$ were performed on the same machine with flow injection: $0.4 \mathrm{~mL} / \mathrm{min}$ in $70 \% \mathrm{~B}$. HPLC analyses were performed with an Agilent 1100 Series HPLC utilizing a column Chromolith Performance RP-18-e 100-4.6 with $29^{\circ} \mathrm{C}$ column temperature, a flow of $2 \mathrm{~mL} / \mathrm{min}$ and a solvent gradient $2 \%$ to $100 \%$ B over $4.5 \mathrm{~min}$, followed by $1 \mathrm{~min}$ at $100 \%$ B; solvent $A$ : water with $0.1 \%$ trifluoroacetic acid, solvent B: acetonitrile with $0.1 \%$ trifluoroacetic acid, and UV-detection at $215 \mathrm{~nm}$. Preparative HPLC was done on a Gilson system with DAD-detector utilizing a 100x30 mm Waters Sunfire Prep C18 OBD ${ }^{\mathrm{TM}} 5 \mu \mathrm{m}$ column with a flow of $30 \mathrm{~mL} / \mathrm{min}$ and a specified solvent gradient using solvent $A$ : water with $0.1 \%$ trifluoroacetic acid, solvent B: acetonitrile.

\section{Step 2-1 N-(5-bromopyridin-3-yl)acetamide}<smiles>CC(=O)Nc1cncc(Br)c1</smiles>

To a solution of 3-amino-5-bromopyridine $(250 \mathrm{mg}, 1.40 \mathrm{mmol})$, anhydrous $\mathrm{CH}_{2} \mathrm{Cl}_{2}(8 \mathrm{~mL})$ and $\mathrm{Et}_{3} \mathrm{~N}(234$ $\mu \mathrm{L}, 1.68 \mathrm{mmol})$ was added dropwise acetyl chloride $(105 \mu \mathrm{L}, 1.48 \mathrm{mmol})$ at rt under stirring. The mixture was stirred at $\mathrm{rt}$ for $1 \mathrm{~h}$. The reaction mixture was diluted with sat. aq. $\mathrm{NaHCO}_{3}$ and extracted with $\mathrm{CH}_{2} \mathrm{Cl}_{2}$ then with EtOAc. The combined organic layers were washed with brine, dried $\left(\mathrm{Na}_{2} \mathrm{SO}_{4}\right)$, filtered, concentrated under reduced pressure and dried under vacuum to afford $307 \mathrm{mg}$ as a beige solid of the title compound (quantitative yield).

HPLC : Rt $=1.96 \mathrm{~min}$

MS : $[\mathrm{M}+\mathrm{H}]^{+}$215.0/217.0., [M-H] $212.9 / 214.9$ (Br pattern)

${ }^{1} \mathrm{H}$ NMR $\left(400 \mathrm{MHz}, \mathrm{DMSO}-\mathrm{d}_{6}\right) \delta 10.36(\mathrm{~s}, 1 \mathrm{H}), 8.62(\mathrm{~d}, \mathrm{~J}=1.5 \mathrm{~Hz}, 1 \mathrm{H}), 8.45-8.26(\mathrm{~m}, 2 \mathrm{H}), 2.09(\mathrm{~s}, 3 \mathrm{H})$.

\section{Step 2-2 N-(5-(1H-pyrrol-2-yl)pyridin-3-yl)acetamide}<smiles>CC(=O)Nc1cncc(-c2ccc[nH]2)c1</smiles>

To a solution of $\mathrm{N}$-(5-bromopyridin-3-yl)acetamide (Step 2-1) (200 mg, $0.91 \mathrm{mmol}), 1$-Boc-pyrrole-2boronic acid pinacol ester (303 mg, $1.00 \mathrm{mmol})$, THF $(6 \mathrm{~mL})$ and $2.4 \mathrm{M}$ aq. $\mathrm{Cs}_{2} \mathrm{CO}_{3}(1.14 \mathrm{~mL}, 2.73 \mathrm{mmol})$ 
flushed with argon was added 1,1' bis(di-tert-butylphosphino)ferrocene palladium dichloride (36 $\mathrm{mg}$, $0.055 \mathrm{mmol})$. The vial was sealed and the reaction mixture was stirred at $50^{\circ} \mathrm{C}$ for $13 \mathrm{~h}$. The reaction mixture was diluted with EtOAc and extracted with brine. The organic layer was dried $\left(\mathrm{Na}_{2} \mathrm{SO}_{4}\right)$, filtered and concentrated to dryness. The resulting brown oil (HPLC : Rt $=2.58 \mathrm{~min}, \mathrm{MS}:[\mathrm{M}+\mathrm{H}]^{+} 302.1,[\mathrm{M}-\mathrm{H}]^{-}$ 300.1), without further purification, was treated in TFA $(3.5 \mathrm{ml})$ at $\mathrm{rt}$ for $1 \mathrm{~h}$. The reaction mixture was taken in $\mathrm{H}_{2} \mathrm{O}$ and extracted with $\mathrm{CH}_{2} \mathrm{Cl}_{2}$. The aq. layer was neutralized $(10 \mathrm{M}$ aq. $\mathrm{NaOH})$, basified $\left(\mathrm{NaHCO}_{3}\right)$ and saturated with $\mathrm{NaCl}$, before being extracted twice with EtOAc. The EtOAc organic layers were combined, washed with brine, dried $\left(\mathrm{Na}_{2} \mathrm{SO}_{4}\right)$, filtered and concentrated to dryness to afford $190 \mathrm{mg}$ as a grey solid of the title compound ( $98 \%$ yield).

HPLC : Rt $=1.95 \mathrm{~min}$

MS : $[\mathrm{M}+\mathrm{H}]^{+}$202.1, [M-H] 200.0

${ }^{1} \mathrm{H}$ NMR $\left(400 \mathrm{MHz}, \mathrm{DMSO}-\mathrm{d}_{6}\right) \delta 11.46(\mathrm{~s}, 1 \mathrm{H}), 10.13(\mathrm{~s}, 1 \mathrm{H}), 8.54(\mathrm{~d}, \mathrm{~J}=1.9 \mathrm{~Hz}, 1 \mathrm{H}), 8.45(\mathrm{~d}, \mathrm{~J}=2.1 \mathrm{~Hz}, 1 \mathrm{H})$, $8.21-8.16(m, 1 H), 6.94-6.88(m, 1 H), 6.54-6.49(m, 1 H), 6.19-6.12(m, 1 H), 2.09(s, 3 H)$.

\section{Compound 2 N-(5-(4-(2,6-dichlorobenzoyl)-1H-pyrrol-2-yl)pyridin-3-yl)acetamide}<smiles>CC(=O)Nc1cncc(-c2cc(C(=O)c3c(Cl)cccc3Cl)c[nH]2)c1</smiles>

To a solution of 2,6-dichlorobenzoyl chloride $\left(88 \mu \mathrm{L}, 0.61 \mathrm{mmol}\right.$ ) in $\mathrm{CH}_{2} \mathrm{Cl}_{2}(5 \mathrm{~mL})$ was added $\mathrm{AlCl}_{3}(126$ $\mathrm{mg}, 0.94 \mathrm{mmol})$ and the suspension was stirred at $\mathrm{rt}$ for $1 \mathrm{~h}$. A suspension of $\mathrm{N}$ - $(5-(1 \mathrm{H}-$ pyrrol-2-yl)pyridin3-yl)acetamide (Step 2-2) (100 mg, $0.47 \mathrm{mmol})$ in $\mathrm{CH}_{2} \mathrm{Cl}_{2}(5 \mathrm{~mL})$ was added and the mixture was stirred at rt for $1 \mathrm{~h} 30 . \mathrm{AlCl}_{3}(126 \mathrm{mg}, 0.94 \mathrm{mmol}$ ) was added and the mixture was stirred at $\mathrm{rt}$ for 24 additional hours. The reaction mixture was quenched by addition of ice, basified (sat. aq. $\mathrm{NaHCO}_{3} / \mathrm{H}_{2} \mathrm{O}: 2 / 1$ ) and extracted with EtOAc. The combined organic layers were washed with $\mathrm{H}_{2} \mathrm{O}$, sat. aq. $\mathrm{NaHCO}_{3}$ and brine. The organic layer was dried $\left(\mathrm{Na}_{2} \mathrm{SO}_{4}\right)$, filtered and concentrated to dryness. The residue was dissolved in DMA and purified by prep. HPLC (Gradient : 3\% to 55\% B in 20 min.). Fractions were collected, basified $\left(\mathrm{NaHCO}_{3}\right)$ and concentrated. The resulting suspension was cooled in the fridge then filtered. The resulting residue was washed with $\mathrm{H}_{2} \mathrm{O}$ and dried under high vaccum to afford $15 \mathrm{mg}$ of a beige solid as the title compound ( $8 \%$ yield).

HPLC : Rt $=2.64 \mathrm{~min}$ MS : $[\mathrm{M}+\mathrm{H}]^{+}$374.0/376.1, [M-H] 372.0/374.0 (2 Cl pattern)

${ }^{1} \mathrm{H}$ NMR $\left(400 \mathrm{MHz}, \mathrm{DMSO}-\mathrm{d}_{6}\right) \delta 12.42(\mathrm{~s}, 1 \mathrm{H}), 10.19(\mathrm{~s}, 1 \mathrm{H}), 8.63(\mathrm{~d}, \mathrm{~J}=1.8 \mathrm{~Hz}, 1 \mathrm{H}), 8.54(\mathrm{~d}, \mathrm{~J}=1.9 \mathrm{~Hz}, 1 \mathrm{H})$, $8.31-8.26(\mathrm{~m}, 1 \mathrm{H}), 7.66-7.48(\mathrm{~m}, 3 \mathrm{H}), 7.39(\mathrm{~s}, 1 \mathrm{H}), 6.88(\mathrm{~s}, 1 \mathrm{H}), 2.10(\mathrm{~s}, 3 \mathrm{H})$. 
Step 3-1 (2,6-dichlorophenyl)(quinolin-6-yl)methanol<smiles>OC(c1ccc2ncccc2c1)c1c(Cl)cccc1Cl</smiles>

To a solution of 6-bromoquinoline $(291 \mathrm{mg}, 1.37 \mathrm{mmol})$ in THF $(7 \mathrm{~mL})$ at $-78^{\circ} \mathrm{C}$ were added 4methylmorpholine $(142 \mathrm{mg}, 1.37 \mathrm{mmol})$, then $1.6 \mathrm{M} \mathrm{N}$-butyllithium in hexane (857 $\mu \mathrm{l}, 1.37 \mathrm{mmol})$ dropwise over $30 \mathrm{~min}$. The reaction mixture was stirred at $-78^{\circ} \mathrm{C}$ for $30 \mathrm{~min}$. Magnesium bromide diethyl etherate $\left(396 \mathrm{mg}, 1.49 \mathrm{mmol}\right.$ ) was added and the reaction mixture was stirred at $-78^{\circ} \mathrm{C}$ for $90 \mathrm{~min}$. A suspension of 2,6-dichlorobenzaldehyde $(200 \mathrm{mg}, 1.14 \mathrm{mmol})$ in THF (2 mL) was added dropwise over 45 min and the reaction mixture was stirred at $-78^{\circ} \mathrm{C}$ for $3.5 \mathrm{~h}$. Sat. aq. $\mathrm{NH}_{4} \mathrm{Cl}(10 \mathrm{~mL})$ was added and the reaction mixture was allowed to warm to $0^{\circ} \mathrm{C}$, then extracted with EtOAc. The organic phase was washed with brine, dried $\left(\mathrm{Na}_{2} \mathrm{SO}_{4}\right)$, filtered and concentrated under reduced pressure to dryness. The residue was purified by silica gel column chromatography $\left(\mathrm{CH}_{2} \mathrm{Cl}_{2} / \mathrm{EtOH}, 98: 2\right)$ to provide after evaporation and drying under vacuum $89 \mathrm{mg}$ of the title compound ( $24 \%$ yield).

LC-MS : Rt $=0.85 \mathrm{~min},[\mathrm{M}+\mathrm{H}]^{+}$304.0/306.0 (2 Cl pattern)

${ }^{1} \mathrm{H}$ NMR (400 MHz, DMSO-d 6 ) $\delta 8.86$ (dd, J = 4.1, $\left.1.5 \mathrm{~Hz}, 1 \mathrm{H}\right), 8.36(\mathrm{~d}, \mathrm{~J}=7.7 \mathrm{~Hz}, 1 \mathrm{H}), 7.95$ (d, J = 8.8 Hz, $1 \mathrm{H}), 7.91(\mathrm{~s}, 1 \mathrm{H}), 7.58(\mathrm{dd}, \mathrm{J}=8.8,1.8 \mathrm{~Hz}, 1 \mathrm{H}), 7.55-7.44(\mathrm{~m}, 3 \mathrm{H}), 7.42-7.33(\mathrm{~m}, 1 \mathrm{H}), 6.69(\mathrm{~d}, \mathrm{~J}=4.8 \mathrm{~Hz}$, $1 \mathrm{H}), 6.47(\mathrm{~d}, \mathrm{~J}=4.8 \mathrm{~Hz}, 1 \mathrm{H})$.

\section{Compound 3 (2,6-dichlorophenyl)(quinolin-6-yl)methanone}<smiles>O=C(c1ccc2ncccc2c1)c1c(Cl)cccc1Cl</smiles>

To a solution of (2,6-dichlorophenyl)(quinolin-6-yl)methanol (Step 3-1) (71 mg, $0.23 \mathrm{mmol}$ ) in $\mathrm{CHCl}_{3}(4 \mathrm{~mL})$ at $\mathrm{rt}$ was added manganese dioxide $(204 \mathrm{mg}, 2.34 \mathrm{mmol}$ ) and the mixture was stirred at $\mathrm{rt}$ for $20 \mathrm{~h}$. Manganese dioxide (204 mg, $2.34 \mathrm{mmol}$ ) was added and the mixture was stirred at $\mathrm{rt} 74$ additional hours. The reaction mixture was filtered over Celite. The resulting solid was washed with a warm solution of $\mathrm{CH}_{2} \mathrm{Cl}_{2} / \mathrm{EtOAC} / \mathrm{MeOH}$ (4:1:1). The resulting solution was concentrated under reduced pressure to dryness. The residue was purified by silica gel column chromatography $\left(\mathrm{CH}_{2} \mathrm{Cl}_{2} / \mathrm{EtOH}, 98: 2\right)$. The residue was triturated in $\mathrm{CH}_{2} \mathrm{Cl}_{2} /$ pentane $1: 7$, filtered and dried under vacuum to provide $27 \mathrm{mg}$ as the title compound in $36 \%$ yield.

LC-MS : Rt = $1.07 \mathrm{~min},[\mathrm{M}+\mathrm{H}]^{+}$301.9/303.9 (2 Cl pattern)

${ }^{1} \mathrm{H}$ NMR $\left(400 \mathrm{MHz}, \mathrm{DMSO}-\mathrm{d}_{6}\right) \delta 9.19-8.89(\mathrm{~m}, 1 \mathrm{H}), 8.61(\mathrm{~d}, \mathrm{~J}=8.2 \mathrm{~Hz}, 1 \mathrm{H}), 8.40(\mathrm{~s}, 1 \mathrm{H}), 8.23-8.08(\mathrm{~m}$, $2 \mathrm{H}), 7.82-7.41(\mathrm{~m}, 4 \mathrm{H})$ 
Step 4-1 N-(2,6-dichlorophenyl)quinolin-6-amine<smiles>Clc1cccc(Cl)c1Nc1ccc2ncccc2c1</smiles>

To a solution of 6-bromoquinoline (300 mg, $1.43 \mathrm{mmol}$ ), 2,6-dichloroaniline (236 mg, $1.43 \mathrm{mmol}$ ) and $\mathrm{Cs}_{2} \mathrm{CO}_{3} \quad(698 \mathrm{mg}, 2.14 \mathrm{mmol})$ in dioxane $(7 \mathrm{~mL})$ under argon were added tris(dibenzylideneacetone)dipalladium(0) chloroform adduct (37 mg, $0.036 \mathrm{mmol}$ ) and 4,5-bis(diphenylphosphino)-9,9-dimethylxanthene $(62 \mathrm{mg}, 0.11 \mathrm{mmol})$. The reaction mixture was sealed and stirred at $100^{\circ} \mathrm{C}$ for $18 \mathrm{~h}$. The reaction mixture was taken in water and extracted with EtOAc. The organic phase was washed with brine, dried $\left(\mathrm{Na}_{2} \mathrm{SO}_{4}\right)$, filtered and concentrated under reduced pressure to dryness. The residue was purified by silica gel column chromatography (EtOAc/heptane, 0:100 to 50:50 in $25 \mathrm{~min}$ ) to provide after evaporation and drying under vacuum $336 \mathrm{mg}$ as a yellow solid of the title compound (81\% yield).

$\mathrm{HPLC}: \mathrm{Rt}=2.70 \mathrm{~min}$

MS : $[\mathrm{M}+\mathrm{H}]^{+}$289.0/291.0 (2 Cl pattern)

${ }^{1} \mathrm{H}$ NMR $(400 \mathrm{MHz}$, DMSO-d 6 ) $\delta 8.59-8.53(\mathrm{~m}, 1 \mathrm{H}), 8.33(\mathrm{~s}, 1 \mathrm{H}), 7.99(\mathrm{~d}, \mathrm{~J}=8.5 \mathrm{~Hz}, 1 \mathrm{H}), 7.82(\mathrm{~d}, \mathrm{~J}=9.1 \mathrm{~Hz}$, $1 \mathrm{H}), 7.60(\mathrm{~d}, \mathrm{~J}=8.2 \mathrm{~Hz}, 2 \mathrm{H}), 7.37-7.26(\mathrm{~m}, 3 \mathrm{H}), 6.52(\mathrm{~d}, \mathrm{~J}=2.5 \mathrm{~Hz}, 1 \mathrm{H})$.

\section{Compound 4 N-(2,6-dichlorophenyl)-N-methylquinolin-6-amine}<smiles>CN(c1ccc2ncccc2c1)c1c(Cl)cccc1Cl</smiles>

To a solution of $\mathrm{N}$-(2,6-dichlorophenyl)quinolin-6-amine (Step 4-1) (40 mg, $0.14 \mathrm{mmol}$ ) in DMF (1.3 mL) under argon was added $55 \% \mathrm{NaH}$ in oil $(8 \mathrm{mg}, 0.18 \mathrm{mmol}$ ) and the mixture was stirred at $\mathrm{rt}$ for $30 \mathrm{~min}$. lodomethane $(10 \mu \mathrm{L}, 0.16 \mathrm{mmol})$ was added and the mixture was stirred at rt for $15 \mathrm{~h}$. The reaction mixture was quenched with one drop of water and diluted in DMF to be purified by prep. HPLC (Gradient : $15 \%$ to $95 \%$ B in 20 min). Fractions were collected, basified $\left(\mathrm{NaHCO}_{3}\right)$ and concentrated. The residue was extracted with EtOAc. The organic phase was washed with brine, dried $\left(\mathrm{Na}_{2} \mathrm{SO}_{4}\right)$, filtered, concentrated under reduced pressure and dried under vacuum to afford $31 \mathrm{mg}$ as an oil of the title compound ( $75 \%$ yield).

HPLC : Rt $=2.95 \mathrm{~min}$ MS : $[\mathrm{M}+\mathrm{H}]^{+}$303.0/305.0 (2 Cl pattern) ${ }^{1} \mathrm{H} \mathrm{NMR}\left(400 \mathrm{MHz}, \mathrm{DMSO}-\mathrm{d}_{6}\right) \delta 8.58(\mathrm{dd}, \mathrm{J}=4.2,1.6 \mathrm{~Hz}, 1 \mathrm{H}), 8.11(\mathrm{~d}, \mathrm{~J}=8.4 \mathrm{~Hz}, 1 \mathrm{H}), 7.77(\mathrm{~d}, \mathrm{~J}=9.2 \mathrm{~Hz}$, $1 \mathrm{H}), 7.67(\mathrm{~d}, \mathrm{~J}=8.1 \mathrm{~Hz}, 2 \mathrm{H}), 7.51-7.42(\mathrm{~m}, 1 \mathrm{H}), 7.36(\mathrm{dd}, \mathrm{J}=8.3,4.2 \mathrm{~Hz}, 1 \mathrm{H}), 6.93(\mathrm{~s}, 1 \mathrm{H}), 6.80(\mathrm{~d}, \mathrm{~J}=8.4$ $\mathrm{Hz}, 1 \mathrm{H}), 3.29(\mathrm{~s}, 3 \mathrm{H})$ 
Step 5-1 6-bromo-4-methoxyquinoline<smiles>COc1ccnc2ccc(Br)cc12</smiles>

To a solution obtained by reacting sodium $(28 \mathrm{mg}, 1.22 \mathrm{mmol}$ ) in $\mathrm{MeOH}(5 \mathrm{~mL})$ under argon was added 6bromo-4-chloroquinoline $(270 \mathrm{mg}, 1.10 \mathrm{mmol})$ and the mixture was heated with microwave irradiation at $100^{\circ} \mathrm{C}$ for $2.5 \mathrm{~h}$. The reaction mixture was quenched with $\mathrm{H}_{2} \mathrm{O}$ and extracted with EtOAc. The organic phase was washed with brine, dried $\left(\mathrm{Na}_{2} \mathrm{SO}_{4}\right)$, filtered and concentrated to dryness to afford $261 \mathrm{mg}$ as an off-white solid of the title compound ( $96 \%$ yield).

HPLC : Rt $=2.31 \mathrm{~min}$

MS : $[\mathrm{M}+\mathrm{H}]^{+} 238.0 / 240.0$ (Br pattern)

${ }^{1} \mathrm{H}$ NMR $\left(400 \mathrm{MHz}, \mathrm{DMSO}-\mathrm{d}_{6}\right) \delta 8.78(\mathrm{~d}, \mathrm{~J}=5.3 \mathrm{~Hz}, 1 \mathrm{H}), 8.27(\mathrm{~d}, \mathrm{~J}=2.1 \mathrm{~Hz}, 1 \mathrm{H}), 7.96-7.82(\mathrm{~m}, 2 \mathrm{H}), 7.10$

$(\mathrm{d}, \mathrm{J}=5.2 \mathrm{~Hz}, 1 \mathrm{H}), 4.06(\mathrm{~s}, 3 \mathrm{H})$

Step 5-2 N-(2,6-dichlorophenyl)-4-methoxyquinolin-6-amine<smiles>COc1ccnc2ccc(Nc3c(Cl)cccc3Cl)cc12</smiles>

To a solution of 6-bromo-4-methoxyquinoline (Step 5-1) (252 mg, $1.03 \mathrm{mmol}$ ), 2,6-dichloroaniline (170 $\mathrm{mg}$, $1.03 \mathrm{mmol}$ ) and $\mathrm{Cs}_{2} \mathrm{CO}_{3}(502 \mathrm{mg}, 1.54 \mathrm{mmol})$ in dioxane $(5 \mathrm{~mL})$ under argon were added tris(dibenzylideneacetone)dipalladium(0) chloroform adduct $(27 \mathrm{mg}, 0.026 \mathrm{mmol}$ ) and 4,5-bis(diphenylphosphino)-9,9-dimethylxanthene ( $45 \mathrm{mg}, 0.077 \mathrm{mmol}$ ). The mixture was flushed with argon, sealed and stirred at $100^{\circ} \mathrm{C}$ for $18.5 \mathrm{~h}$. The reaction mixture was quenched with $\mathrm{H}_{2} \mathrm{O}$ and extracted with EtOAc. The organic phase was washed with brine, dried $\left(\mathrm{Na}_{2} \mathrm{SO}_{4}\right)$, filtered and concentrated to dryness. The residue was purified by silica gel column chromatography (EtOAc/heptane, 0:100 to 100:0 in $25 \mathrm{~min}$ ) to provide after evaporation and drying under vacuum $232 \mathrm{mg}$ as a yellow solid of the title compound (69\% yield).

$\mathrm{HPLC}: \mathrm{Rt}=2.87 \mathrm{~min}$

MS : $[\mathrm{M}+\mathrm{H}]^{+} 319.0 / 321.0$ (2 Cl pattern)

${ }^{1} \mathrm{H} \mathrm{NMR}\left(400 \mathrm{MHz}, \mathrm{DMSO}-\mathrm{d}_{6}\right) \delta 8.43(\mathrm{~d}, \mathrm{~J}=5.1 \mathrm{~Hz}, 1 \mathrm{H}), 8.29(\mathrm{~s}, 1 \mathrm{H}), 7.76(\mathrm{~d}, \mathrm{~J}=9.0 \mathrm{~Hz}, 1 \mathrm{H}), 7.60(\mathrm{~d}, \mathrm{~J}=8.1$ $\mathrm{Hz}, 2 \mathrm{H}), 7.32(\mathrm{t}, \mathrm{J}=8.1 \mathrm{~Hz}, 1 \mathrm{H}), 7.25(\mathrm{dd}, \mathrm{J}=9.1,2.6 \mathrm{~Hz}, 1 \mathrm{H}), 6.84(\mathrm{~d}, \mathrm{~J}=5.1 \mathrm{~Hz}, 1 \mathrm{H}), 6.77(\mathrm{~d}, \mathrm{~J}=2.6 \mathrm{~Hz}$, $1 \mathrm{H}), 3.89(\mathrm{~s}, 3 \mathrm{H})$ 
<smiles>COc1ccnc2ccc(N(C)c3c(Cl)cccc3Cl)cc12</smiles>

To a solution of $\mathrm{N}$-(2,6-dichlorophenyl)-4-methoxyquinolin-6-amine (Step 5-2) (35 mg, $0.11 \mathrm{mmol}$ ) in DMF (1 mL) under argon was added $55 \% \mathrm{NaH}$ in oil $(7 \mathrm{mg}, 0.15 \mathrm{mmol})$ and the mixture was stirred at $\mathrm{rt}$ for $30 \mathrm{~min}$. lodomethane ( $9 \mu \mathrm{L}, 0.14 \mathrm{mmol}$ ) was added and the mixture was stirred at $\mathrm{rt}$ for $2 \mathrm{~h}$. The mixture was quenched with few drops of $\mathrm{H}_{2} \mathrm{O}$, diluted with DMF and purified by prep. HPLC (Gradient : $5 \%$ to $95 \%$ B in $20 \mathrm{~min})$. Fractions were collected, basified $\left(\mathrm{NaHCO}_{3}\right)$ and concentrated. The residue was extracted with EtOAc. The organic phase was washed with brine, dried $\left(\mathrm{Na}_{2} \mathrm{SO}_{4}\right)$, filtered, concentrated under reduced pressure and dried under high vacuum to afford $26 \mathrm{mg}$ as a yellow solid of the title compound ( $73 \%$ yield).

HPLC : Rt $=3.13 \mathrm{~min}$

MS : $[\mathrm{M}+\mathrm{H}]^{+} 333.0 / 335.0$ (2 Cl pattern)

${ }^{1} \mathrm{H}$ NMR $\left(400 \mathrm{MHz}, \mathrm{DMSO}-\mathrm{d}_{6}\right) \delta 8.47(\mathrm{~d}, \mathrm{~J}=5.1 \mathrm{~Hz}, 1 \mathrm{H}), 7.75(\mathrm{~d}, \mathrm{~J}=9.2 \mathrm{~Hz}, 1 \mathrm{H}), 7.68(\mathrm{~d}, \mathrm{~J}=8.3 \mathrm{~Hz}, 2 \mathrm{H})$, $7.52-7.43(\mathrm{~m}, 1 \mathrm{H}), 7.00(\mathrm{~s}, 1 \mathrm{H}), 6.90(\mathrm{~d}, \mathrm{~J}=5.1 \mathrm{~Hz}, 1 \mathrm{H}), 6.84(\mathrm{~d}, \mathrm{~J}=8.5 \mathrm{~Hz}, 1 \mathrm{H}), 3.98(\mathrm{~s}, 3 \mathrm{H}), 3.29(\mathrm{~s}, 3 \mathrm{H})$.

Step 6-1 6-bromo-3-(4-methoxybenzyl)quinazolin-4(3H)-one<smiles>COc1ccc(Cn2cnc3ccc(Br)cc3c2=O)cc1</smiles>

To a solution of 6-bromoquinazolin-4-ol (2.08 g, $9.15 \mathrm{mmol}$ ) in DMF (35 mL) under argon was added 55\% $\mathrm{NaH}$ in oil (439 mg, $10.1 \mathrm{mmol}$ ) and the mixture was stirred at rt for $30 \mathrm{~min}$. 4-Methoxybenzyl chloride $(1.52 \mathrm{~mL}, 11.0 \mathrm{mmol}$ ) was added and the mixture was stirred at $\mathrm{rt}$ for $145 \mathrm{~min}$. The reaction was quenched with $\mathrm{H}_{2} \mathrm{O}$ and the precipitate was filtered, washed with water and dried under vacuum to give $3.05 \mathrm{~g}$ as an off-white solid of the title compound (95\% yield).

$\mathrm{HPLC}: \mathrm{Rt}=3.33 \mathrm{~min}$

MS : $[\mathrm{M}+\mathrm{H}]^{+} 345.1 / 347.1$ (Br pattern)

${ }^{1} \mathrm{H}$ NMR (400 MHz, DMSO-d $\left.)_{6}\right) 8.61(\mathrm{~s}, 1 \mathrm{H}), 8.23(\mathrm{~d}, \mathrm{~J}=2.3 \mathrm{~Hz}, 1 \mathrm{H}), 7.97(\mathrm{dd}, \mathrm{J}=8.6,2.3 \mathrm{~Hz}, 1 \mathrm{H}), 7.64(\mathrm{~d}$, $\mathrm{J}=8.7 \mathrm{~Hz}, 1 \mathrm{H}), 7.34(\mathrm{~d}, \mathrm{~J}=8.6 \mathrm{~Hz}, 2 \mathrm{H}), 6.90(\mathrm{~d}, \mathrm{~J}=8.7 \mathrm{~Hz}, 2 \mathrm{H}), 5.12(\mathrm{~s}, 2 \mathrm{H}), 3.71(\mathrm{~s}, 3 \mathrm{H})$. 
Step 6-2 6-((2,6-dichlorophenyl)amino)-3-(4-methoxybenzyl)quinazolin-4(3H)-one<smiles>COc1ccc(Cn2cnc3ccc(Nc4c(Cl)cccc4Cl)cc3c2=O)cc1</smiles>

To a solution of 6-bromo-3-(4-methoxybenzyl)quinazolin-4(3H)-one (Step 6-1) (3.05 g, 8.75 mmol), 2,6dichloroaniline $(1.45 \mathrm{~g}, 8.75 \mathrm{mmol}), \mathrm{Cs}_{2} \mathrm{CO}_{3}(4.28 \mathrm{~g}, 13.1 \mathrm{mmol})$ in dioxane $(40 \mathrm{~mL})$ under argon were added tris(dibenzylideneacetone)dipalladium(0) chloroform adduct $(226 \mathrm{mg}, 0.219 \mathrm{mmol}$ ) and 4,5bis(diphenyl-phosphino)-9,9-dimethylxanthene (380 mg, $0.656 \mathrm{mmol}$ ). The mixture was flushed with argon and stirred at $100^{\circ} \mathrm{C}$ for $19 \mathrm{~h}$. The mixture was diluted with $\mathrm{H}_{2} \mathrm{O}$ and extracted twice with EtOAc. The combined organic layers were washed with brine, dried $\left(\mathrm{Na}_{2} \mathrm{SO}_{4}\right)$, filtered and concentrated under reduced pressure to dryness. The residue was purified by silica gel column chromatography (EtOAc/heptane, 0:100 to 50:50 in $30 \mathrm{~min}$ ) to provide after evaporation and drying under vacuum $2.64 \mathrm{~g}$ as an off-white foam of the title compound (69\% yield).

HPLC : Rt $=3.39 \mathrm{~min}$

MS : $[\mathrm{M}+\mathrm{H}]^{+} 426.2 / 428.2$ (2 Cl pattern)

${ }^{1} \mathrm{H}$ NMR (400 MHz, DMSO-d 6 ) $\delta 8.42(\mathrm{~s}, 1 \mathrm{H}), 8.30(\mathrm{~s}, 1 \mathrm{H}), 7.59(\mathrm{~d}, \mathrm{~J}=8.1 \mathrm{~Hz}, 2 \mathrm{H}), 7.52(\mathrm{~d}, \mathrm{~J}=8.8 \mathrm{~Hz}, 1 \mathrm{H})$, $7.33(\mathrm{t}, 1 \mathrm{H}), 7.30-7.25(\mathrm{~m}, 2 \mathrm{H}), 7.19(\mathrm{dd}, \mathrm{J}=8.9,2.8 \mathrm{~Hz}, 1 \mathrm{H}), 6.93(\mathrm{~d}, \mathrm{~J}=2.7 \mathrm{~Hz}, 1 \mathrm{H}), 6.88-6.83(\mathrm{~m}, 2 \mathrm{H})$, $5.03(\mathrm{~s}, 2 \mathrm{H}), 3.69(\mathrm{~s}, 3 \mathrm{H})$.

Step 6-3 6-((2,6-dichlorophenyl)amino)quinazolin-4(3H)-one<smiles>O=c1[nH]cnc2ccc(Nc3c(Cl)cccc3Cl)cc12</smiles>

A solution of 6-((2,6-dichlorophenyl)amino)-3-(4-methoxybenzyl)quinazolin-4(3H)-one (Step 6-2) (2.63 $\mathrm{mg}, 6.05 \mathrm{mmol})$ in TFA $/ \mathrm{H}_{2} \mathrm{O} 20 / 1(18.9 \mathrm{~mL})$ was stirred at $90^{\circ} \mathrm{C}$ for 2 days. The mixture was concentrated to dryness. The residue was dissolved in $\mathrm{CH}_{2} \mathrm{Cl}_{2}$ and washed with sat. aq. $\mathrm{NaHCO}_{3}$. The organic layer was washed with brine, dried $\left(\mathrm{Na}_{2} \mathrm{SO}_{4}\right)$, filtered and concentrated under reduced pressure to dryness. The residue was purified by silica gel column chromatography $\left(\mathrm{CH}_{2} \mathrm{Cl}_{2} / \mathrm{MeOH}, 100: 0\right.$ to $94: 6$ in $\left.30 \mathrm{~min}\right)$ to provide after evaporation and drying under vacuum $1.64 \mathrm{~g}$ as a green solid of the title compound $(88 \%$ yield).

HPLC : Rt $=2.66 \mathrm{~min}$

MS : $[\mathrm{M}+\mathrm{H}]^{+} 306.1 / 308.1,[\mathrm{M}-\mathrm{H}]^{-} 304.0 / 306.1$ (2 Cl pattern)

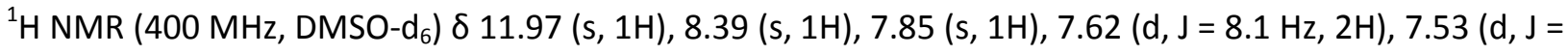
$8.7 \mathrm{~Hz}, 1 \mathrm{H}), 7.35(\mathrm{t}, 1 \mathrm{H}), 7.21(\mathrm{dd}, \mathrm{J}=8.7,2.8 \mathrm{~Hz}, 1 \mathrm{H}), 6.93(\mathrm{~d}, \mathrm{~J}=2.8 \mathrm{~Hz}, 1 \mathrm{H})$. 
<smiles>Clc1cccc(Cl)c1Nc1ccc2ncnc(Cl)c2c1</smiles>

A solution of 6-((2,6-dichlorophenyl)amino)quinazolin-4(3H)-one (Step 6.3) (1.63 g, $5.27 \mathrm{mmol}$ )and 1 drop of DMF in $\mathrm{POCl}_{3}(25 \mathrm{~mL}, 268 \mathrm{mmol})$ under argon was stirred at $100^{\circ} \mathrm{C}$ for $3 \mathrm{~h}$. The mixture was concentrated to dryness. The residue was dissolved in $\mathrm{CH}_{2} \mathrm{Cl}_{2}$ and washed twice with sat. aq. $\mathrm{NaHCO}_{3}$ and with brine, dried $\left(\mathrm{Na}_{2} \mathrm{SO}_{4}\right)$, filtered, concentrated under reduced pressure and dried under vacuum to afford $1.73 \mathrm{~g}$ as a green solid of the title compound (99\% yield).

HPLC : Rt $=3.45 \mathrm{~min}$

LC-MS : Rt = $1.15 \mathrm{~min},[\mathrm{M}+\mathrm{H}]^{+} 324.1 / 326.1[\mathrm{M}-\mathrm{H}]^{-} 322.0 / 324.0$ (3 Cl pattern)

${ }^{1} \mathrm{H}$ NMR $\left(400 \mathrm{MHz}, \mathrm{DMSO}-\mathrm{d}_{6}\right) \delta 8.96(\mathrm{~s}, 1 \mathrm{H}), 8.78(\mathrm{~s}, 1 \mathrm{H}), 7.93(\mathrm{~d}, \mathrm{~J}=9.1 \mathrm{~Hz}, 1 \mathrm{H}), 7.65(\mathrm{~d}, \mathrm{~J}=8.1 \mathrm{~Hz}, 2 \mathrm{H})$, $7.55(\mathrm{dd}, \mathrm{J}=9.1,2.6 \mathrm{~Hz}, 1 \mathrm{H}), 7.39(\mathrm{t}, 1 \mathrm{H}), 6.81(\mathrm{~d}, \mathrm{~J}=2.6 \mathrm{~Hz}, 1 \mathrm{H})$.

\section{Step 6-5 N6-(2,6-dichlorophenyl)quinazoline-4,6-diamine}<smiles>Nc1ncnc2ccc(Nc3c(Cl)cccc3Cl)cc12</smiles>

A solution of 4-chloro-N-(2,6-dichlorophenyl)quinazolin-6-amine (Step 6-4) (600 mg, $1.81 \mathrm{mmol}$ ) and 0.5 $\mathrm{M}$ ammonia in dioxane $(28 \mathrm{~mL}, 14.0 \mathrm{mmol})$ under argon was splitted in two and heated with microwave irradiation at $170^{\circ} \mathrm{C}$ for $16 \mathrm{~h}$. The reaction mixtures were diluted with EtOAc and washed with $\mathrm{H}_{2} \mathrm{O}$ and brine. The combined aq. layers were extracted with EtOAc and the combined organic layers were dried $\left(\mathrm{Na}_{2} \mathrm{SO}_{4}\right)$, filtered, concentrated under reduced pressure and dried under vacuum to afford $629 \mathrm{mg}$ as a brown solid of the crude title compound ( $97 \%$ yield).

HPLC : Rt $=2.49 \mathrm{~min}$ MS : $[\mathrm{M}+\mathrm{H}]^{+}$305.1/307.1, [M-H] $303.1 / 305.1$ (2 Cl pattern)

${ }^{1} \mathrm{H}$ NMR (400 MHz, DMSO-d $\left.\mathrm{d}_{6}\right) \delta 8.17(\mathrm{~s}, 1 \mathrm{H}), 8.12(\mathrm{~s}, 1 \mathrm{H}), 7.56(\mathrm{~d}, \mathrm{~J}=8.1 \mathrm{~Hz}, 2 \mathrm{H}), 7.52(\mathrm{~d}, \mathrm{~J}=8.9 \mathrm{~Hz}, 1 \mathrm{H})$, $7.37-7.23(\mathrm{~m}, 4 \mathrm{H}), 6.86(\mathrm{~d}, \mathrm{~J}=2.5 \mathrm{~Hz}, 1 \mathrm{H})$. 
Compound 6 N6-(2,6-dichlorophenyl)-N6-(prop-2-yn-1-yl)quinazoline-4,6-diamine<smiles>C#CCN(c1ccc2ncnc(N)c2c1)c1c(Cl)cccc1Cl</smiles>

To a solution of N6-(2,6-dichlorophenyl)quinazoline-4,6-diamine (Step 6-5) (200 mg, $0.557 \mathrm{mmol}$ ) in DMF $(3 \mathrm{~mL})$ under argon was added $55 \% \mathrm{NaH}$ in oil $(29.2 \mathrm{mg}, 0.668 \mathrm{mmol})$ and the mixture was stirred at $\mathrm{rt}$ for $20 \mathrm{~min} .80 \%$ Bromopropargyl in toluene $(0.078 \mathrm{~mL}, 0.724 \mathrm{mmol})$ was added and the mixture was stirred at $\mathrm{rt}$ for $105 \mathrm{~min}$. The reaction was quenched with 3 drops of $\mathrm{H}_{2} \mathrm{O}$, filtered and purified by prep. HPLC (Gradient : 3\% to 50\% B in 20 min; 2 runs). Fractions were collected, basified $\left(\mathrm{NaHCO}_{3}\right)$ and concentrated. The product crystallized in $\mathrm{H}_{2} \mathrm{O}$. The solid was filtered, washed with water and dried under vacuum to afford $123 \mathrm{mg}$ as a white solid of the title compound (64\% yield).

HPLC : Rt $=2.76 \mathrm{~min}$

MS : $[\mathrm{M}+\mathrm{H}]^{+} 343.1 / 345.1$ (2 Cl pattern)

${ }^{1} \mathrm{H}$ NMR $\left(400 \mathrm{MHz}, \mathrm{DMSO}-\mathrm{d}_{6}\right) \delta 8.21(\mathrm{~s}, 1 \mathrm{H}), 7.66(\mathrm{~d}, \mathrm{~J}=8.1 \mathrm{~Hz}, 2 \mathrm{H}), 7.58-7.41(\mathrm{~m}, 4 \mathrm{H}), 7.34(\mathrm{~d}, \mathrm{~J}=2.7 \mathrm{~Hz}$, $1 \mathrm{H}), 6.76(\mathrm{dd}, \mathrm{J}=9.1,2.6 \mathrm{~Hz}, 1 \mathrm{H}), 4.54(\mathrm{~d}, \mathrm{~J}=2.5 \mathrm{~Hz}, 2 \mathrm{H}), 3.21(\mathrm{t}, \mathrm{J}=2.5 \mathrm{~Hz}, 1 \mathrm{H})$.

Compound 7 N6-(2,6-dichlorophenyl)-N6-(3-(5-methylpyridin-2-yl)prop-2-yn-1yl)quinazoline-4,6-diamine<smiles>Cc1ccc(C#CCN(c2ccc3ncnc(N)c3c2)c2c(Cl)cccc2Cl)nc1</smiles>

A solution of N6-(2,6-dichlorophenyl)-N6-(prop-2-yn-1-yl)quinazoline-4,6-diamine (compound 6) (30 mg, $0.087 \mathrm{mmol}$ ), 2-bromo-5-methylpyridine (16 mg, $0.091 \mathrm{mmol}$ ), Cul (1.7 mg, $0.0089 \mathrm{mmol}), \mathrm{Pd}\left(\mathrm{PPh}_{3}\right)_{2} \mathrm{Cl}_{2}$ $(1.9 \mathrm{mg}, 0.0027 \mathrm{mmol})$ in triethylamine $(0.7 \mathrm{~mL})$ and NMP $(0.08 \mathrm{ml})$ under argon was stirred at $\mathrm{rt}$ for $17 \mathrm{~h}$. The solvent was blown-off with $\mathrm{N}_{2}$ and the residue was taken in DMF, filtered and purifed by prep. HPLC (Gradient : $3 \%$ to $70 \% \mathrm{~B}$ in $20 \mathrm{~min}$ ). Fractions were collected, basified $\left(\mathrm{NaHCO}_{3}\right)$, concentrated and extracted twice with $\mathrm{CH}_{2} \mathrm{Cl}_{2}$. The organic layers were washed with brine, dried $\left(\mathrm{Na}_{2} \mathrm{SO}_{4}\right)$, filtered, evaporated and dried under vacuum to afford $24 \mathrm{mg}$ as an off-white foam of the title compound (63\% yield). 
HPLC : Rt $=2.72 \mathrm{~min}$

LC-MS : Rt $=0.85 \mathrm{~min},[\mathrm{M}+\mathrm{H}]^{+} 434.2 / 436.2$ (2 Cl pattern)

${ }^{1} \mathrm{H}$ NMR $\left(400 \mathrm{MHz}, \mathrm{DMSO}-\mathrm{d}_{6}\right) \delta 8.36(\mathrm{~d}, \mathrm{~J}=2.0 \mathrm{~Hz}, 1 \mathrm{H}), 8.23(\mathrm{~s}, 1 \mathrm{H}), 7.69(\mathrm{~d}, \mathrm{~J}=8.2 \mathrm{~Hz}, 2 \mathrm{H}), 7.63-7.39(\mathrm{~m}$, $6 \mathrm{H}), 7.20(\mathrm{~d}, \mathrm{~J}=7.9 \mathrm{~Hz}, 1 \mathrm{H}), 6.81(\mathrm{dd}, \mathrm{J}=9.2,2.2 \mathrm{~Hz}, 1 \mathrm{H}), 4.81(\mathrm{~s}, 2 \mathrm{H}), 2.28(\mathrm{~s}, 3 \mathrm{H})$.

Step 8-1 1-(2-((tert-butyldimethylsilyl)oxy)-1H-imidazole-2-carbaldehyde<smiles>CC(C)(C)[Si](C)(C)OCCn1ccnc1C=O</smiles>

A solution of imidazole-2-carboxaldehyde $(500 \mathrm{mg}, 5.05 \mathrm{mmol})$, potassium carbonate $(2.1 \mathrm{~g}, 15.2 \mathrm{mmol})$ and (2-bromoethoxy)-tert-butyldimethylsilane $(1.3 \mathrm{~mL}, 6.06 \mathrm{mmol})$ in DMF $(7 \mathrm{~mL})$ was sealed and stirred at $55^{\circ} \mathrm{C}$ for $21 \mathrm{~h}$. The reaction mixture was quenched with $\mathrm{H}_{2} \mathrm{O}$ and extracted twice with EtOAc. The combined organic layers were washed with $\mathrm{H}_{2} \mathrm{O}$, twice with brine, dried $\left(\mathrm{Na}_{2} \mathrm{SO}_{4}\right)$, filtered, concentrated under reduced pressure and dried under vacuum. The residue was purified by silica gel column chromatography (heptane/EtOAc, 100:0 to 30:70 in $15 \mathrm{~min}$ ) to provide after evaporation and drying under vacuum $800 \mathrm{mg}$ as a yellow oil of the title compound (62\% yield).

HPLC : Rt $=2.71 \mathrm{~min}$

$\mathrm{MS}:[\mathrm{M}+\mathrm{H}]^{+} 255.2$

${ }^{1} \mathrm{H}$ NMR $\left(400 \mathrm{MHz}, \mathrm{DMSO}-\mathrm{d}_{6}\right) \delta 9.70(\mathrm{~d}, \mathrm{~J}=0.8 \mathrm{~Hz}, 1 \mathrm{H}), 7.62-7.58(\mathrm{~m}, 1 \mathrm{H}), 7.28(\mathrm{~d}, \mathrm{~J}=1.0 \mathrm{~Hz}, 1 \mathrm{H}), 4.48(\mathrm{t}$, $\mathrm{J}=5.3 \mathrm{~Hz}, 2 \mathrm{H}), 3.84(\mathrm{t}, \mathrm{J}=5.1 \mathrm{~Hz}, 2 \mathrm{H}), 0.78(\mathrm{~s}, 9 \mathrm{H}),-0.12(\mathrm{~s}, 6 \mathrm{H})$.

Step 8-2 N6-(2,6-dichlorophenyl)-N6-(3-(5-methylpyridin-2-yl)prop-2-yn-1yl)quinazoline-4,6-diamine<smiles>CO[Si](C)(OCCn1ccnc1[C@H](O)C#CCN(c1ccc2ncnc(N)c2c1)c1c(Cl)cccc1Cl)C(C)(C)C</smiles> 
To a solution of N6-(2,6-dichlorophenyl)-N6-(prop-2-yn-1-yl)quinazoline-4,6-diamine (compound 6) (30 $\mathrm{mg}, 0.087 \mathrm{mmol}$ ) and $0.5 \mathrm{ml}$ anhydrous THF under argon was added a $1 \mathrm{M}$ ethyl magnesium bromide solution in THF $(0.35 \mathrm{ml}, 0.35 \mathrm{mmol})$ and the reaction mixture was stirred at $\mathrm{rt}$ for $1 \mathrm{~h}$. The reaction mixture was added onto 1-(2-((tert-butyldimethylsilyl)oxy)-1H-imidazole-2-carbaldehyde (step 8-1) (156 $\mathrm{mg}, 0.612 \mathrm{mmol}$ ) and stirred at $\mathrm{rt}$ for $20 \mathrm{~min}$. The solvent was blown-off with $\mathrm{N}_{2}$ and the residue was taken in DMF, filtered and separated by prep. HPLC (Gradient : 5\% to 95\% B in $20 \mathrm{~min}$ ). Fractions containing product were collected, basified $\left(\mathrm{NaHCO}_{3}\right)$, concentrated and extracted twice with $\mathrm{CH}_{2} \mathrm{Cl}_{2}$. The organic layers were washed with brine, dried $\left(\mathrm{Na}_{2} \mathrm{SO}_{4}\right)$, filtered, evaporated and dried under vacuum to afford $61 \mathrm{mg}$ as a yellow sticky oil of the impure title compound (65\% yield).

HPLC : Rt $=3.07 \mathrm{~min}$

LC-MS : Rt = $0.92 \mathrm{~min},[\mathrm{M}+\mathrm{H}]^{+}$597.3/599.3, [M-H] 595.2/597.2 (2 Cl pattern)

Compound 8 4-((4-aminoquinazolin-6-yl)(2,6-dichlorophenyl)amino)-1-(1-(2hydroxyethyl)-1H-imidazol-2-yl)but-2-yn-1-ol<smiles>Nc1ncnc2ccc(N(CC#C[C@H](O)c3nccn3CCO)c3c(Cl)cccc3Cl)cc12</smiles>

A solution of N6-(2,6-dichlorophenyl)-N6-(3-(5-methylpyridin-2-yl)prop-2-yn-1-yl)quinazoline-4,6diamine (step 8-2) $(60 \mathrm{mg}, 0.056 \mathrm{mmol})$ in THF (1 ml) was treated with HF-pyridine $(0.6 \mathrm{ml}, 6.9 \mathrm{mmol})$ at $\mathrm{rt}$ for $1.5 \mathrm{~h}$. The reaction mixture was poured dropwise onto sat. aq. $\mathrm{NaHCO}_{3}$ and then extracted twice with EtOAc. The combined organic layers were washed with sat. aq. $\mathrm{NaHCO}$ and brine, dried $\left(\mathrm{Na}_{2} \mathrm{SO}_{4}\right)$, filtered, concentrated under reduced pressure and dried under vacuum. The residue was taken in DMF, filtered and purifed by prep. HPLC (Gradient : 3\% to 50\% B in 20 min). Fractions were collected, basified $\left(\mathrm{NaHCO}_{3}\right)$, concentrated and extracted twice with $\mathrm{CH}_{2} \mathrm{Cl}_{2}$ and twice with EtOAc. The combined organic layers were washed with brine, dried $\left(\mathrm{Na}_{2} \mathrm{SO}_{4}\right)$, filtered, evaporated and dried under vacuum to afford 6 $\mathrm{mg}$ as an off-white solid of the title compound ( $22 \%$ yield).

$\mathrm{HPLC}: \mathrm{Rt}=2.22 \mathrm{~min}$

MS : $[\mathrm{M}+\mathrm{H}]^{+}$483.2/485.2, [M-H] 481.1/483.1 (2 Cl pattern )

${ }^{1} \mathrm{H}$ NMR (400 MHz, DMSO-d 6 ) $\delta 8.19(\mathrm{~s}, 1 \mathrm{H}), 7.59(\mathrm{~d}, \mathrm{~J}=8.0 \mathrm{~Hz}, 2 \mathrm{H}), 7.53-7.46(\mathrm{~m}, 2 \mathrm{H}), 7.46-7.39(\mathrm{~m}$, $2 \mathrm{H}), 7.33(\mathrm{~d}, \mathrm{~J}=2.6 \mathrm{~Hz}, 1 \mathrm{H}), 7.06(\mathrm{~d}, \mathrm{~J}=1.2 \mathrm{~Hz}, 1 \mathrm{H}), 6.77-6.69(\mathrm{~m}, 2 \mathrm{H}), 6.09(\mathrm{~d}, \mathrm{~J}=5.5 \mathrm{~Hz}, 1 \mathrm{H}), 5.47-$

$5.41(\mathrm{~m}, 1 \mathrm{H}), 4.90(\mathrm{t}, \mathrm{J}=5.0 \mathrm{~Hz}, 1 \mathrm{H}), 4.57(\mathrm{t}, \mathrm{J}=2.2 \mathrm{~Hz}, 2 \mathrm{H}), 4.20-4.08(\mathrm{~m}, 1 \mathrm{H}), 3.90-3.79(\mathrm{~m}, 1 \mathrm{H}), 3.55$ (q, J $=5.5 \mathrm{~Hz}, 2 \mathrm{H}$ ). 
Step 9-1 6-((2,6-dichlorophenyl)amino)-3-methylquinazolin-4(3H)-one<smiles>Cn1cnc2ccc(Nc3c(Cl)cccc3Cl)cc2c1=O</smiles>

To a solution of 6-bromo-3-methylquinazolin-4(3H)-one (685 mg, $2.81 \mathrm{mmol}$ ), 2,6-dichloroaniline (500 $\mathrm{mg}, 3.09 \mathrm{mmol}), \mathrm{Cs}_{2} \mathrm{CO}_{3}(1.37 \mathrm{~g}, 4.21 \mathrm{mmol})$ in anhydrous dioxane $(11 \mathrm{~mL})$ were added tris(dibenzylideneacetone)dipalladium(0) chloroform adduct (73 mg, $0.071 \mathrm{mmol}$ ) and 4,5-bis(diphenylphosphino)-9,9-dimethylxanthene (122 $\mathrm{mg}, 0.21 \mathrm{mmol}$ ). The reaction mixture was flushed with argon, the vial was sealed and the mixture was stirred at $100^{\circ} \mathrm{C}$ for $17.25 \mathrm{~h}$. The reaction mixture was diluted with EtOAc and washed with sat. aq. $\mathrm{NaHCO}_{3}$. The organic layer was washed with brine, dried $\left(\mathrm{Na}_{2} \mathrm{SO}_{4}\right)$, filtered and concentrated under reduced pressure to dryness. The residue was taken in hot $\mathrm{MeOH}$, sonicated then cooled in the fridge. The resulting suspension was filtered. The solid was washed with $\mathrm{MeOH}$. The filtrate was concentrated. The residue was taken in hot $\mathrm{CH}_{3} \mathrm{CN}$, sonicated then cooled in the fridge and filtered. The resulting solid was washed with few $\mathrm{CH}_{3} \mathrm{CN}$. Both solids were recombined and dried to afford $663 \mathrm{mg}$ as an off-white solid of the title compound (73\% yield).

HPLC : Rt $=2.92 \mathrm{~min}$

MS : $[\mathrm{M}+\mathrm{H}]^{+} 320.1 / 322.1(2 \mathrm{Cl}$ pattern )

${ }^{1} \mathrm{H}$ NMR $\left(400 \mathrm{MHz}, \mathrm{DMSO}-\mathrm{d}_{6}\right) \delta 8.42(\mathrm{~s}, 1 \mathrm{H}), 8.14(\mathrm{~s}, 1 \mathrm{H}), 7.63(\mathrm{~d}, \mathrm{~J}=8.1 \mathrm{~Hz}, 2 \mathrm{H}), 7.54(\mathrm{~d}, \mathrm{~J}=8.8 \mathrm{~Hz}, 1 \mathrm{H})$,

$7.35(\mathrm{t}, \mathrm{J}=8.1 \mathrm{~Hz}, 1 \mathrm{H}), 7.21(\mathrm{dd}, \mathrm{J}=8.8,2.8 \mathrm{~Hz}, 1 \mathrm{H}), 6.99(\mathrm{~d}, \mathrm{~J}=2.7 \mathrm{~Hz}, 1 \mathrm{H}), 3.44(\mathrm{~s}, 3 \mathrm{H})$.

Step 9-2 6-((2,6-dichlorophenyl)(prop-2-yn-1-yl)amino)-3-methylquinazolin-4(3H)one<smiles>C#CCN(c1ccc2ncn(C)c(=O)c2c1)c1c(Cl)cccc1Cl</smiles>

To a solution of 6-((2,6-dichlorophenyl)amino)-3-methylquinazolin-4(3H)-one (Step 9-1) (654 mg, 2.02 $\mathrm{mmol})$ in anhydrous DMF (8 mL) was added $60 \% \mathrm{NaH}$ in oil $(97 \mathrm{mg}, 4.23 \mathrm{mmol})$ and the mixture was stirred at $\mathrm{rt}$ for $30 \mathrm{~min}$. $80 \%$ bromopropargyl in toluene $(283 \mu \mathrm{L}, 2.63 \mathrm{mmol}$ ) was added and the mixture was stirred at $\mathrm{rt}$ for $2 \mathrm{~h}$. The reaction was quenched with $\mathrm{H}_{2} \mathrm{O}$, diluted with sat. aq. $\mathrm{NaHCO}_{3}$ and extracted twice with EtOAc. The organic layers were washed with brine, dried $\left(\mathrm{Na}_{2} \mathrm{SO}_{4}\right)$, filtered and concentrated under reduced pressure to dryness. The residue was dissolved in $\mathrm{CH}_{2} \mathrm{Cl}_{2}$ and purified by silica gel column chromatography $\left(\mathrm{CH}_{2} \mathrm{Cl}_{2} / \mathrm{MeOH}, 100: 0\right.$ to $94: 6$ in $\left.25 \mathrm{~min}\right)$ to provide $671 \mathrm{mg}$ as a beige solid of the title compound ( $92 \%$ yield).

HPLC : Rt $=3.18 \mathrm{~min}$ MS : $[\mathrm{M}+\mathrm{H}]^{+} 358.2 / 360.2(2 \mathrm{Cl}$ pattern )

${ }^{1} \mathrm{H}_{\mathrm{NMR}}\left(400 \mathrm{MHz}, \mathrm{DMSO}-\mathrm{d}_{6}\right) \delta 8.18(\mathrm{~s}, 1 \mathrm{H}), 7.69(\mathrm{~d}, \mathrm{~J}=8.1 \mathrm{~Hz}, 2 \mathrm{H}), 7.57(\mathrm{~d}, \mathrm{~J}=9.0 \mathrm{~Hz}, 1 \mathrm{H}), 7.50(\mathrm{dd}, \mathrm{J}=$ 
8.5, 7.8 Hz, 1H), $7.18(d, J=2.7 \mathrm{~Hz}, 1 \mathrm{H}), 7.00(\mathrm{dd}, 1 \mathrm{H}), 4.52(\mathrm{~d}, \mathrm{~J}=2.4 \mathrm{~Hz}, 2 \mathrm{H}), 3.46(\mathrm{~s}, 3 \mathrm{H}), 3.29(\mathrm{t}, \mathrm{J}=2.4$ $\mathrm{Hz}, 1 \mathrm{H})$.

Compound 9 6-((2,6-dichlorophenyl)(3-(pyridin-3-yl)prop-2-yn-1-yl)amino)-3methylquinazolin-4(3H)-one<smiles>Cn1cnc2ccc(N(CC#Cc3cccnc3)c3c(Cl)cccc3Cl)cc2c1=O</smiles>

To a solution of 6-((2,6-dichlorophenyl)(prop-2-yn-1-yl)amino)-3-methylquinazolin-4(3H)-one (Step 9-2) (45 mg, $0.13 \mathrm{mmol}$ ), 3-iodopyridine (36 mg, $0.18 \mathrm{mmol}$ ), Cul $(2 \mathrm{mg}, 10.5 \mu \mathrm{mol}), \mathrm{Pd}(\mathrm{PhCN})_{2} \mathrm{Cl}_{2}(6 \mathrm{mg}$, $0.016 \mathrm{mmol})$ in dioxane $(0.3 \mathrm{~mL})$ were added tri-tert-butylphosphonium tetrafluoroborate $(9 \mathrm{mg}, 0.031$ $\mathrm{mmol}$ ) then diisopropylamine $(24 \mu \mathrm{L}, 0.17 \mathrm{mmol})$ and the mixture was stirred at rt under argon for 17.75 h. The reaction mixture was blown-off with $\mathrm{N}_{2}$. The residue was dissolved in DMF, filtered and purified by prep. HPLC (Gradient: $5 \%$ to $95 \%$ B in $20 \mathrm{~min}$ ). Fractions were collected, basified $\left(\mathrm{NaHCO}_{3}\right)$ and concentrated. The sticky oily suspension was separated, washed with water and dissolved in $\mathrm{CH}_{2} \mathrm{Cl}_{2}$. The organic phase was washed with brine and dried $\left(\mathrm{Na}_{2} \mathrm{SO}_{4}\right)$, filtered and concentrated to dryness to afford $11 \mathrm{mg}$ as an off-white foam of the title compound ( $20 \%$ yield).

HPLC : Rt $=2.96 \mathrm{~min}$

$\mathrm{MS}:[\mathrm{M}+\mathrm{H}]^{+} 435.2 / 437.2(2 \mathrm{Cl}$ pattern)

${ }^{1} \mathrm{H}$ NMR $\left(400 \mathrm{MHz}, \mathrm{DMSO}-\mathrm{d}_{6}\right) \delta 8.53(\mathrm{dd}, \mathrm{J}=4.9,1.6 \mathrm{~Hz}, 1 \mathrm{H}), 8.48(\mathrm{~d}, \mathrm{~J}=2.1,0.7 \mathrm{~Hz}, 1 \mathrm{H}), 8.17(\mathrm{~s}, 1 \mathrm{H}), 7.76$

$-7.67(\mathrm{~m}, 3 \mathrm{H}), 7.58(\mathrm{~d}, \mathrm{~J}=9.0 \mathrm{~Hz}, 1 \mathrm{H}), 7.51(\mathrm{dd}, \mathrm{J}=8.5,7.8 \mathrm{~Hz}, 1 \mathrm{H}), 7.42-7.34(\mathrm{~m}, 1 \mathrm{H}), 7.24(\mathrm{~d}, \mathrm{~J}=2.8 \mathrm{~Hz}$, $1 \mathrm{H}), 7.06(\mathrm{dd}, \mathrm{J}=9.0,2.8 \mathrm{~Hz}, 1 \mathrm{H}), 4.81(\mathrm{~s}, 2 \mathrm{H}), 3.45(\mathrm{~s}, 3 \mathrm{H})$.

Compound 10 6-((2,6-dichlorophenyl)(3-(2-methylpyrimidin-5-yl)prop-2-yn-1yl)amino)-3-methylquinazolin-4(3H)-one<smiles>Cc1ncc(C#CCN(c2ccc3ncn(C)c(=O)c3c2)c2c(Cl)cccc2Cl)cn1</smiles> 
A solution of 6-((2,6-dichlorophenyl)(prop-2-yn-1-yl)amino)-3-methylquinazolin-4(3H)-one (step 9-2) (40 $\mathrm{mg}, 0.11 \mathrm{mmol}), 5$-bromo-2-methylpyrimidine (22 $\mathrm{mg}, 0.12 \mathrm{mmol})$, Cul $(2 \mathrm{mg}, 0.012 \mathrm{mmol}$ ) and $\mathrm{Pd}\left(\mathrm{PPh}_{3}\right)_{2} \mathrm{Cl}_{2}(2.4 \mathrm{mg}, 3.42 \mu \mathrm{mol})$ in $\mathrm{Et}_{3} \mathrm{~N}(0.8 \mathrm{~mL})$ and NMP $(100 \mu \mathrm{L})$ was stirred under argon at rt for 19.5 h. The reaction mixture was blown-off with $\mathrm{N}_{2}$. The residue was dissolved in DMF, filtered and purified by prep. HPLC (Gradient: $5 \%$ to $95 \%$ B in $20 \mathrm{~min}$ ). Fractions were collected, basified $\left(\mathrm{NaHCO}_{3}\right)$ and concentrated. The sticky oily suspension was separated, washed with water and dissolved in $\mathrm{CH}_{2} \mathrm{Cl}_{2}$. The organic phase was washed with brine and dried $\left(\mathrm{Na}_{2} \mathrm{SO}_{4}\right)$, filtered and concentrated to dryness to afford $11 \mathrm{mg}$ as an off-white foam of the title compound ( $22 \%$ yield).

HPLC : Rt $=3.30 \mathrm{~min}$

MS : $[\mathrm{M}+\mathrm{H}]^{+} 450.2 / 452.1$ (2 Cl pattern )

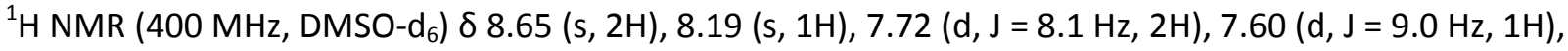
$7.52(\mathrm{t}, \mathrm{J}=8.1 \mathrm{~Hz}, 1 \mathrm{H}), 7.24(\mathrm{~d}, \mathrm{~J}=2.5 \mathrm{~Hz}, 1 \mathrm{H}), 7.07(\mathrm{dd}, \mathrm{J}=8.9,2.8 \mathrm{~Hz}, 1 \mathrm{H}), 4.85(\mathrm{~s}, 2 \mathrm{H}), 3.46(\mathrm{~s}, 3 \mathrm{H}), 2.62$ $(\mathrm{s}, 3 \mathrm{H})$.

\section{Dot1L scintillation proximity assay (SPA)}

For $\mathrm{IC}_{50}$ determination, compounds were pre-incubated with Dot1L(2-416) for 30 min before the reaction was started by addition of $S$-[methyl- ${ }^{3} \mathrm{H}-$ ] adenosyl-L-methionine $\left({ }^{3} \mathrm{H}-\mathrm{SAM}\right)$ (Perkin Elmer, 18-20 Ci/mmol) and biotinylated nucleosomes (Wuxi Biortus Biosciences Ltd, China). Final concentrations in an assay volume of $10 \mu \mathrm{L}$ were $0.5 \mathrm{nM}$ Dot1L, $200 \mathrm{nM}$ SAM (corresponds to SAM $\mathrm{K}_{\mathrm{M}}$ ) and $60 \mathrm{nM}$ nucleosomes. The assay buffer contained $20 \mathrm{mM}$ Tris $\mathrm{pH} 8,10 \mathrm{mM} \mathrm{MgCl}_{2}$ and $0.01 \%$ Tween-20. Following a reaction time of $90 \mathrm{~min}$ (180 min for assay containing $0.05 \mathrm{nM}$ Dot1L), the reaction was stopped/quenched by the addition of $5 \mu \mathrm{L} 4.5 \mathrm{mg} / \mathrm{mL}$ Streptavidin SPA Beads (Perkin Elmer, RPNQ0006) diluted in $300 \mathrm{mM}$ MES (pH 6) and $600 \mu \mathrm{M}$ SAM (A7007, Sigma). Plates were centrifuged and read on a Topcount NXT HTS (Packard) and IC50 data was analysed using XLFit 5.2 (idbs).

\section{Dot1L surface plasmon resonance assay (SPR)}

Ligand association and dissociation rates were determined by surface plasmon resonance (SPR) using a BiacoreTM T100 (GE Healthcare). Biotinylated hDot1L (2-416)-Avi was immobilized on a Streptavidincoated sensorchip (GE Healthcare, BR-1005-31) to a density of 5000-8000 RU. The running buffer contained $25 \mathrm{mM}$ HEPES, $100 \mathrm{mM} \mathrm{NaCl}, 0.05 \%$ Tween-20, $1 \mathrm{mM}$ TCEP, 1\% DMSO, pH 8. Experiments were carried out at $20^{\circ} \mathrm{C}$. SAH (Sigma A9384) was used as internal control resulting in $\mathrm{K}_{\mathrm{D}} 100 \mathrm{nM}$ under these conditions. Curve fitting was performed using the Biacore T100 Evaluation software.

\section{Experimental procedure for the generation of the Dot $1 \mathrm{~L}$ cocrystal structures}

Dot1L crystals were grown at $20{ }^{\circ} \mathrm{C}$ using the hanging drop vapor diffusion method. Purified Dot1L methyltransferase domain (aa2-aa332) at $8 \mathrm{mg} / \mathrm{ml}$ in $20 \mathrm{mM}$ Tris pH 8.0, $200 \mathrm{mM} \mathrm{NaCl}, 1 \mathrm{mM}$ TCEP, 1 $\mathrm{mM}$ EDTA was pre-incubated with inhibitor compounds at final concentrations between 1-2 mM resulting in a DMSO concentration of $4-10 \%$. For crystallization the protein inhibitor complex was mixed with an equal volume of a reservoir solution. Seeding was applied prior to sealing the setups. Seed stocks were made out of previously obtained Dot $1 \mathrm{~L}$ crystals. Three different reservoir conditions have been identified 
yielding Dot1 $\mathrm{L}$ co-crystals. Condition one is $1.0-1.6 \mathrm{M}$ potassium sodium tartrate tetrahydrate, $0.1 \mathrm{M}$ Hepes $\mathrm{pH}$ 6.6-7.2. The second condition is 1.3-1.6 M lithium sulfate monohydrate, $0.1 \mathrm{M}$ Hepes or Tris $\mathrm{pH}$ 7.0-8.5. Finally, the third reservoir composition is 0.9-1.4 M lithium sulfate monohydrate, 0.1-0.3 M ammonium sulfate, $0.1 \mathrm{M}$ sodium citrate tribasic dihydrate. Prior to flash cooling the crystals in liquid nitrogen, they were rapidly soaked in reservoir solution containing $20-25 \%$ ethylene glycol. In some cases inhibitor compounds were added to the cryo buffer as well. During data acquisition, the crystal temperature was kept at $100 \mathrm{~K}$. Diffraction data were collected at the Swiss Light Source (beamline $\mathrm{X}$ 10SA) using a Pilatus pixel detector with an incident monochromatic X-ray beam. Raw diffraction data were processed and scaled using XDS/XSCALE ${ }^{1}$ software. The structure was determined by molecular

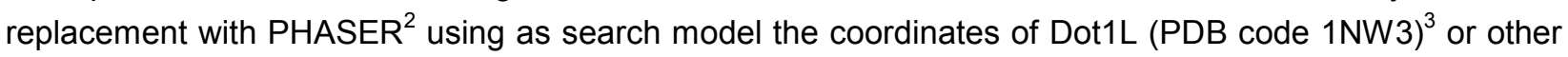
previously solved in-house structures of Dot1L. The program BUSTER ${ }^{4}$ was used for full structure refinement. The refined coordinates of the complex structures have been deposited in the RCSB Protein Data Bank.

\section{References}

(1) Kabsch, W. XDS. Acta Cryst. 2005, D66, 125-132.

(2) McCoy, A. J.; Grosse-Kunstleve, R. W.; Adams, P. D.; Winn, M. D.; Storoni, L. C.; Read, R. J. Phaser crystallographic software. J. Appl. Crystallogr. 2007, 40, 658-674.

(3) Min, J.; Feng, Q; Li, Z.; Zhang, Y.; Xu, R. M. Structure of the catalytic domain of human DOT1L, a nonSET domain nucleosomal histone methyltransferase. Cell 2003, 112, 711-723.

(4) Bricogne, G.; Blanc, E.; Brandl, M.; Flensburg, C.; Keller, P.; Paciorek, W.; Roversi, P.; Sharff, A.; Smart, O. S.; Vonrhein, C.; Womack, T. O. BUSTER version 2.11.4. Cambridge, United Kingdom: Global Phasing Ltd. 2011. 